\title{
Establishing glucosylglycerol synthesis in potato (Solanum tuberosum (. cv. Albatros) by expression of the ggpPS gene from Azotobacter vinelandii
}

\author{
Nanette Sievers ${ }^{1}$, Katja Muders², Manja Henneberg ${ }^{1}$, Stephan Klähn ${ }^{1,3}$, Martin Effmert ${ }^{2}$, Holger Junghans ${ }^{2}$ and Martin Hagemann ${ }^{1 *}$ \\ *Correspondence: martin.hagemann@uni-rostock.de \\ 'Universität Rostock, Institut für Biowissenschaften, Abteilung Pflanzenphysiologie, Albert- Einstein-Str. 3, D-18051 Rostock, \\ Germany. \\ ${ }^{2}$ NORIKA, Nordring- Kartoffelzucht- und Vermehrungs-GmbH, Parkweg 4, D-18190 Sanitz OT Groß Lüsewitz, Germany. \\ ${ }^{3}$ Stephan Klähn, University Freiburg, Inst. Biology III, Genetic and Experimental Bioinformatic, Schaenzlestr. 1, D-79104 \\ Freiburg, Germany.
}

\begin{abstract}
Plants and bacteria synthesize compatible solutes to adapt towards various environmental stress conditions. Moderate halotolerant cyanobacteria and some heterotrophic bacteria accumulate the compatible solute glucosylglycerol (GG), a compound not commonly found in higher plants. We aimed to investigate whether GG can be produced in potato and if it has an improving effect regarding stress tolerance. Potato plants were transformed with the ggpPS gene of Azotobacter vinelandii, which codes the bifunctional enzyme GG-phosphate phosphate/synthase (GgpPS) catalyzing the two-step synthesis of GG. Potato plants were generated expressing ggpPS under control of the constitutive CaMV-35S promoter or the stress-inducible rd29A promoter. The integration of T-DNA in transgenic clones was verified by PCR and transgene expression was detected on mRNA level. Transgenic potatoes with constitutive ggpPS expression accumulated GG up to 19 $\mu \mathrm{mol} / \mathrm{g}$ fresh mass (FM) in leaves but no GG in tubers, while plants with rd29A-controlled ggpPS expression contained 10 $\mu \mathrm{mol}$ GG/g FM in leaves and up to $2.6 \mu \mathrm{mol} \mathrm{GG/g} \mathrm{FM} \mathrm{in} \mathrm{tubers.} \mathrm{In} \mathrm{greenhouse} \mathrm{experiments,} \mathrm{an} \mathrm{increased} \mathrm{shoot} \mathrm{growth} \mathrm{of}$ the GG-accumulating potato plants was observed under salt and drought stress conditions. These results demonstrate that GG synthesis can be achieved in potato plants and might have a protective role on plant metabolism.
\end{abstract}

Keywords: Salt stress, drought stress, compatible solute, glucosylglycerol

\section{Introduction}

Drought and elevated soil salinity limit the distribution and productivity of crop plants worldwide. Therefore, improvement of drought and salt tolerance is an important challenge in modern plant breeding. To achieve this goal classical breeding techniques as well as genetic engineering are used $[\mathbf{1}, \mathbf{2}, \mathbf{3}]$. Central for successful salt acclimation is the avoidance of high concentrations of toxic ions in the cytosol by active extrusion or compartmentation of ions and a parallel accumulation of socalled compatible solutes in metabolic active parts of the cell. The compatible solutes act by enhancing the internal osmotic potential and thereby improving the water status of the cell. In addition, they are able to protect proteins and membranes directly against denaturation $[4,5]$.

An increased accumulation of compatible solutes in plants was obtained by two strategies: (i) by the enhancement of synthesis or the reduction of breakdown of naturally occurring compatible solutes, e.g. proline [6] or trehalose [7], or (ii) by the expression of transgenes, which encode pathways for the synthesis of compatible solutes from halotolerant (micro) organisms (for reviews see $[\mathbf{8 , 9}]$ ). Different chemical classes of compatible solutes were successfully transferred, e.g. the carbohydrate trehalose [10,11], the polyols mannitol [12] and sorbitol [13], or the amino acid derivatives glycine betaine [14,15] and ectoine [16]. Although the transgenes were expressed in most of the cases, the detected levels of compatible solutes were either relatively low $(0.01-4.6 \mu \mathrm{mol} / \mathrm{g}$ fresh mass (FM)) or the accumulation was accompanied by pleiotrophic effects, when the detectable levels of these osmolytes were rather high (e.g. for sorbitol accumulation in transgenic tobacco, [13]). However, an improved growth of the transgenic plants under drought, high salt, cold, or high light stress conditions has been reported in several cases $[\mathbf{9 , 1 1 ]}$.

Microorganisms such as the photoautotrophic cyanobacteria adapted to almost all habitats on Earth including extreme environments such as hypersaline ponds. The molecular biology of the cyanobacterial salt acclimation has been intensively studied using different model strains [17]. Moderate halotolerant cyanobacteria accumulate the heteroside 2-O-(aD-glucopyranosyl)-glycerol (glucosylglycerol, GG) as main compatible solute [18]. The biosynthesis of GG resembles the twostep synthesis mechanism of trehalose or sucrose [19]. Thereby, glycerol 3-phosphate and ADP-glucose are converted by the activity of the GG-phosphate synthase to GG-phosphate, which is dephosphorylated in a second step by the specific GG-phosphate phosphatase resulting in GG $[\mathbf{2 0}, \mathbf{2 1}, \mathbf{2 2}]$. Beside cyanobacteria, GG was also found in salt-treated heterotrophic bacteria [23,24]. For the salt-induced GG synthesis these bacteria express the 
bi-functional protein GG-phosphate phosphatase/synthase (GgpPS) that is composed of an N-terminal phosphatase domain fused to a C-terminal synthase domain, thus this enzyme can catalyze both reactions. Moreover, the GgpPS enzymes were shown to accept ADP-glucose as well as UDP-glucose as glucosyldonors [25]. The resurrection plant Myrothamnus flabellifolia represents the only known land plant species accumulating GG under drought stress [26], while some Liliaceae synthesize it constitutively [27]. However, so far nothing is known about the GG synthesis mechanism in these plants. Additional to the osmotic function in the natural GGaccumulating cells, the protective ability of GG was verified, because it protects soluble enzymes as well as membranes against denaturation in vitro $[\mathbf{2 8}, \mathbf{2 9}]$.

Recently we reported that the transfer of the GG biosynthesis enzyme GgpPS from the rhizobacterium Azotobacter vinelandii into the model Arabidopsis thaliana led to GG accumulation and improved stress tolerance [30]. In the present study we aimed to investigate if GG synthesis can also be achieved in the crop plant Solanum tuberosum. Such transgenic crop plants may show sustainable growth under saline or drought conditions. Moreover, significant GG accumulation in potato tubers could be used as raw material for $\mathrm{GG}$ purification, which is used under the trade name glycoin in cosmetics or pharmaceuticals as moisture or stabilizer (http://www.bitop.de; [31]).

\section{Material and Methods}

\section{Plant material, bacteria and growth media}

Potato plants (Solanum tuberosum L. cv. Albatros) were obtained from the "NORIKA GmbH" (Germany). In vitro cultured plants were maintained on Murashige Skoog (MS) medium [32] in plastic containers under a $16 \mathrm{~h}$ light $\left(22^{\circ} \mathrm{C}\right) / 8 \mathrm{~h}$ dark $\left(18^{\circ} \mathrm{C}\right)$ regime at $90 \mu \mathrm{mol}$ photons $/ \mathrm{m}^{2} / \mathrm{s}$. Approximately $3 \mathrm{~cm}$ long shoots were cut and transferred onto fresh medium under sterile conditions every 8 weeks. In vitro plants were then transferred directly onto soil (4:1 mixture of soil (Type VM Mini Tray; Einheitserdewerk, Uetersen) and vermiculite, soaked with $0.2 \%$ Wuxal liquid fertilizer (Aglukon)), in which they differentiated roots. Regenerated potato plants were grown in a greenhouse on soil in pots of $20 \mathrm{~cm}$ diameter containing $7.5 \mathrm{I}$ soil. Greenhouse control conditions were set to $16 \mathrm{~h} \mathrm{light}$ $\left(22^{\circ} \mathrm{C}\right) / 8 \mathrm{~h}$ dark $\left(20^{\circ} \mathrm{C}\right)$ regime at approximately $180 \mu \mathrm{mol}$ photons $/ \mathrm{m}^{2} / \mathrm{s}$. The plants were watered every second day for $15 \mathrm{~min}$ by an automated table water supply.

The vectors pLH9000 [33], pCambia1305.1 (Cambia), and their derivatives were propagated in E. coli strain TG1 and Agrobacterium tumefaciens strain GV3101 grown on LB medium (Roth) at $37^{\circ} \mathrm{C}$ and $28^{\circ} \mathrm{C}$, respectively.

Construction of vectors used for plant transformation For experiments with constitutive expression of the ggpPS from Azotobacter by the CaMV $35 \mathrm{~S}$ promoter, we used the vector pLH-AF as described previously [30]. In order to generate a vector expressing ggpPS via the stress-inducible rd29A promoter [34], the ggpPS gene was amplified using the primers AFggpPS-Hpal-5' (5'-CGTTAACATGCTACTTGCCACCGA-3') and AFggpPS-Hpal-3' (5'-CGTTAACTCAGGCGATGGCGCGGA-3'), which generated an $\mathrm{Hpal}$ restriction site at each end of the ggpPS coding sequence. The PCR product was then inserted into the vector pGEM-T (Promega) and sequenced. Correct ggpPS gene fragments were obtained by $\mathrm{Hpal}$ restriction and then fused to the CaMV 355 promoter and terminator in the Smal-cut pGreen 35S-2 cassette-vector. The $r d 29 \mathrm{~A}$ upstream region from Arabidopsis thaliana was amplified using primers that were described by [34] and modified by adding a $5^{\prime}$-HindIII (rd29A-5'-HindIII; 5'-CAAGCTTCGACTCAAAACAAACTTACG-3') and 3'-BamHI (rd29A-3'-BamHI; 5'-CGGATCCAATCAAACCCTTTATTCCTG-3') restriction site, respectively. The PCR product was cloned in the PGEM-T vector and verified by sequence analysis. By using the restriction enzymes Hindlll and BamHI, the rd29A promoter fragment was obtained and inserted upstream of the ggpPS gene. Subsequently, the entire expression cassette containing rd29A promoter, ggpPS coding sequence and CaMV $35 \mathrm{~S}$ terminator was cleaved out via restriction by HindIII and EcoRV and cloned into the vector pGreenII0229. Finally, the expression cassette was obtained via restriction by $\mathrm{Kpnl}$ and $X b a l$ and transferred into pCambia1305.1, which harbors the hygromycin phosphotransferase gene (hptll) for transgenic plant selection. The resulting vector was named pCambiard29A-AF.

\section{Generation of transgenic potato plants}

The vectors $\mathrm{pLH}-\mathrm{AF}$ and $\mathrm{pCambia}$-rd29A-AF were transformed into $A$. tumefaciens strain GV3101. For potato transformation stem and leaf explants as well as plasmid-harboring $A$. tumefaciens were co-cultivated in 2 XMS liquid medium ( $0.48 \%$ MS salts including vitamins, $2 \%$ sucrose, $\mathrm{pH}$ 5.7) containing $200 \mu \mathrm{M}$ acetosyringon for $2 \mathrm{~d}$ at $22^{\circ} \mathrm{C}$. The stem and leaf explants were washed with $2 x M S$ liquid medium containing $250 \mathrm{mg} / \mathrm{L}$ cefotaxim and were subsequently transferred to callus induction medium $(0.48 \% \mathrm{MS}$ salts containing vitamins, $1.6 \%$ glucose, $5 \mu \mathrm{g} / \mathrm{ml}$ 1-naphthaleneacetic acid (NAA), $0.1 \mu \mathrm{g} / \mathrm{ml}$ benzylaminopurine, $250 \mu \mathrm{g} / \mathrm{ml}$ cefotaxime, $50 \mu \mathrm{g} / \mathrm{ml}$ kanamycin or $40 \mu \mathrm{g} / \mathrm{ml}$ hygromycin, $0.8 \%$ agar, $\mathrm{pH}$ 5.7). After approximately 7 days, calli appeared and were transferred to shoot induction medium $(0.48 \% \mathrm{MS}$ salts containing vitamins, $1.6 \%$ glucose, $0.02 \mu \mathrm{g} / \mathrm{ml} \mathrm{NAA}, 0.02$ $\mu \mathrm{g} / \mathrm{ml}$ gibberellic acid, $2 \mu \mathrm{g} / \mathrm{ml}$ zeatin riboside, $250 \mu \mathrm{g} / \mathrm{ml}$ cefotaxime, $50 \mu \mathrm{g} / \mathrm{ml}$ kanamycin or $40 \mu \mathrm{g} / \mathrm{ml}$ hygromycin, $0.8 \%$ agar, pH 5.7). Every 7 to 10 days, calli were transferred onto fresh shoot induction medium. Regenerated shoots were transferred on root induction medium $(0.48 \% \mathrm{MS}$ salts containing vitamins, $2.5 \%$ sucrose, $0.1 \mu \mathrm{g} / \mathrm{ml}$ indole-3-acetic acid, $200 \mu \mathrm{g} / \mathrm{ml}$ cefotaxime, $80 \mu \mathrm{g} / \mathrm{ml}$ kanamycin or $40 \mu \mathrm{g} / \mathrm{ml}$ hygromycin, $0.8 \%$ agar, $\mathrm{pH} 5.7)$. Only transgenic clones capable to accumulate GG were kept. We obtained 21 independent GG-accumulating clones of the series Alba-AF, whereas 17 
independent GG-containing clones were regenerated for the series Alba-rd29A-AF. The occurrence of the corresponding transgenes in DNA of transgenic potato clones was verified using PCR (primers for ggpPS: 5'-AGCCTGCTGCAATGCGACTA-3' and $5^{\prime}$-GGTGACATAGGCCAACTGGA-3'; nptll: 5' - AACAGACAATCGGCTGCTCTGATG-3' and 5'-CGCCAAGCTCTTCAGCAATATCAC-3'; hptll: $5^{\prime}$ - ARCCGGTCGGCATCTACTCTAT- $3^{\prime}$ and 5'-TTAGCGAGAGCCTGACCTATTG-3').

\section{Extraction of total RNA for RT-PCR}

For RNA gel blots, total RNA from leaves of the transgenic potato plants was extracted using the Invisorb Spin PlantRNA Mini Kit (Invitek). For RT-PCR the Ready-To-Go RT Beads Kit (Amersham Pharmacia Biotech) was used. The first strand CDNA synthesis was carried out with the random primer $\operatorname{pd}(\mathrm{N}) 6$ and amplification of transgene specific cDNA was carried out with gene specific primer ggpPS RT fwd (5'-AGCCTGCTGCAATGCGACTA-3') and ggpPS RT rev (5'-TGAAGGCGACGATGTCGAAC-3'). The cDNA amounts were equalized according to the PCR product of the constitutively expressed 605 rRNA which was amplified using the primers 60s RT fwd (5'-GACAAGGCTGGAATGACTCACATTGTC-3') and 60s RT rev (5'-CTCCTCAAGAGCAACACGAGAGGTCTG-3').

\section{Low molecular mass compound analysis}

GG and other low molecular mass compounds were determined by gas-liquid chromatography [25]. These substances were extracted from $100 \mathrm{mg}$ plant tissue. After homogenization, the material was treated with $1 \mathrm{ml} 80 \%$ ethanol (containing 50 $\mu \mathrm{g}$ sorbitol as internal standard) at $68^{\circ} \mathrm{C}$ for $2 \mathrm{~h}$, and then with $500 \mu \mathrm{l} 80 \%$ ethanol at $68^{\circ} \mathrm{C}$ over night. After centrifugation $\left(20,000 \mathrm{~g}, 10 \mathrm{~min}, 4^{\circ} \mathrm{C}\right)$ the supernatants were combined, dried in a vacuum centrifuge and re-suspended in $500 \mu \mathrm{l}$ A. dest.. After a further centrifugation step, the supernatant was again evaporated by vacuum centrifugation. The pellets were re-suspended in $65 \mu \mathrm{l}$ pyridine containing $20 \mathrm{mg} / \mathrm{ml}$ methoxylamine at $30^{\circ} \mathrm{C}$ for $90 \mathrm{~min}$. Then, $35 \mu \mathrm{N}$-methyl-Ntrimethylsilyl-trifluoracetamide were added. Subsequently, samples were incubated at $60^{\circ} \mathrm{C}$ for $1 \mathrm{~h}$ and centrifuged $(20,000 \mathrm{~g})$. Aliquots of the supernatants were injected into the gas-chromatograph (GC Focus including FID detector and Auto Sampler AS3000, Thermo Scientific).

\section{Green house experiments}

For the growth experiments transgenic plants from in vitro culture were planted in soil $(7.5 \mathrm{I}$ pots with $20 \mathrm{~cm}$ diameter) and transferred into a greenhouse (long day, $16 \mathrm{~h} \mathrm{light}\left(22^{\circ} \mathrm{C}\right) / 8 \mathrm{~h}$ dark $\left(20^{\circ} \mathrm{C}\right)$ regime at approximately $180 \mu \mathrm{mol}$ photons $\left./ \mathrm{m}^{2} / \mathrm{s}\right)$. Wild-type and transgenic plants (three independent clones with each five individuals from each series were selected) were first cultivated for 4 weeks under control conditions (see above). After this growth phase, the pre-stress samples were collected ( $3^{\text {rd }}$ and $7^{\text {th }}$ leaf from the top), frozen in liquid nitrogen and stored at $-80^{\circ} \mathrm{C}$. Then, the stress treatments were started and continued for the next 4 weeks. Preliminary experiments with wild-type plants were performed to define stress conditions affecting the potato growth without toxic effects. Accordingly, five individuals from each clone or wild type were held at normal irrigation (control, watered with $150 \mathrm{ml}$ every day), five other plants were irrigated with $150 \mathrm{ml}$ water containing 100 $\mathrm{mM} \mathrm{NaCl}$ (salt stress, the salt addition summed up to a final concentration of $60 \mathrm{mM}$ per pot volume), or irrigated with one half of the amount of water used for control conditions (75 $\mathrm{ml}$, drought stress). At defined time points (1, 2, 3, or 4 weeks after onset of stress, i.e., with $5,6,7,8$ weeks old plants) or at the end of the 4 weeks stress period (i.e., 8 weeks old plants, just before starting flowering) samples were taken for GC analyses. Shoot growth of every plant was determined once a week. Shoot branches were removed to ensure comparable measurements of the main shoot. Due to space limitations, this pot size did not allow a reliable estimation of tuber yield. Each greenhouse experiment was repeated 3times.

Statistical significant differences were verified using $\mathrm{t}$-test $(P$-values $=0.5)$.

\section{Results}

Generation and selection of transgenic potatoes

To establish the GG biosynthesis in potato, the gene ggpPS for GG-phosphate phosphatase and GG-phosphate synthase from Azotobacter vinelandii [25] was first cloned under the control of the constitutive CaMV $35 \mathrm{~S}$ promoter (series Alba$\mathrm{AF}$ ). None of the selected transgenic plants showed obvious morphological differences in comparison to the wild type. The integration of the T-DNA in the potato genome was confirmed by PCR. This analysis showed the expected DNA fragment pattern: (i) in wild-type plants no transgene could be detected; (ii) for transgenic plants of the Alba-AF series the occurrence of nptll and ggpPS; and, (iii) for transgenic plants of the Alba-rd29A-AF series the occurrence of hptll and ggpPS were verified (Figure 1).

\section{Expression of $g g p P S$ in transgenic potato plants}

Selected clones of the series Alba-AF were analyzed for expression of ggpPS at mRNA levels using RT-PCR analyses (Figure 2). These semi-quantitative data showed expression of the ggpPS gene in various organs: young and old leaves, stolons as well as tubers. Furthermore, the expression data indicate that the expression level of transgenes under control of the CaMV $35 \mathrm{~S}$ promoter is almost similar in the different plant organs and showed no direct correlation with the GG contents (discussed below).

\section{Biosynthesis of glucosylglycerol (GG)}

The presence of GG in the transgenic potato plants verified that the ggpPS gene was not only transcribed but translated into an enzymatic active protein. The independently obtained transgenic clones of the series Alba-AF showed great differences 

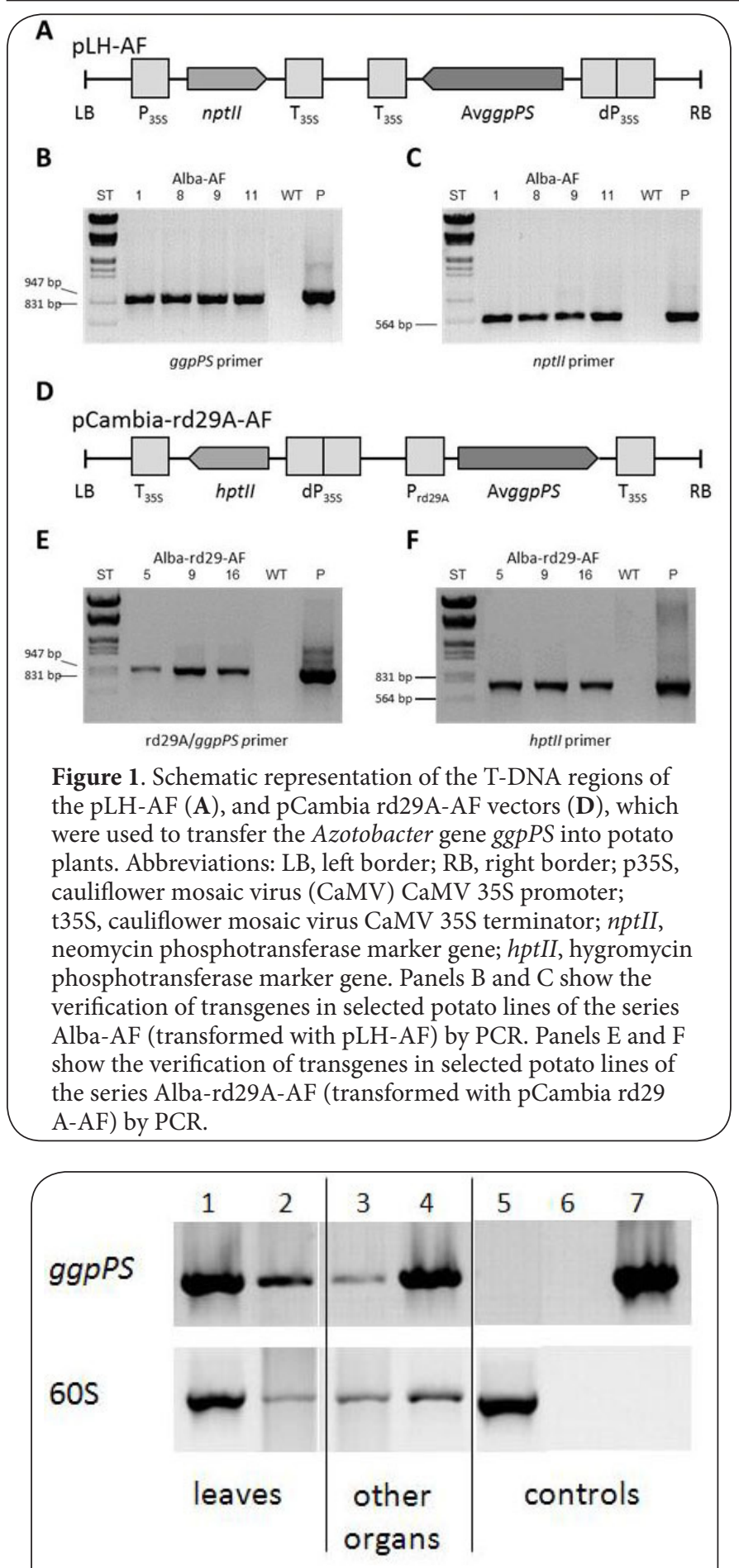

Figure 2. Expression analysis by RT-PCR of $g g p P S$ in transgenic plants. RT-PCR of $g g p P S$ fragments obtained with total leaf RNA from wild type plants and different transgenic plants. Specific primer combinations for amplification of $g g p P S$ and 60S RNA (loading control) were used. 1 - RNA from young leaf of Alba-AF1, 2 -RNA from old leaf of Alba-AF1, 3 - RNA from stolon of AlbaAF1, 4 - RNA from tuber of Alba-AF1, 5 - RNA from young leaf of wild type, 6 - RNA of young leaf of AlbaAF1 with heat-inactivated reverse transcriptase, 7 - DNA of transformation vector $\mathrm{PLH}-\mathrm{AF}$.
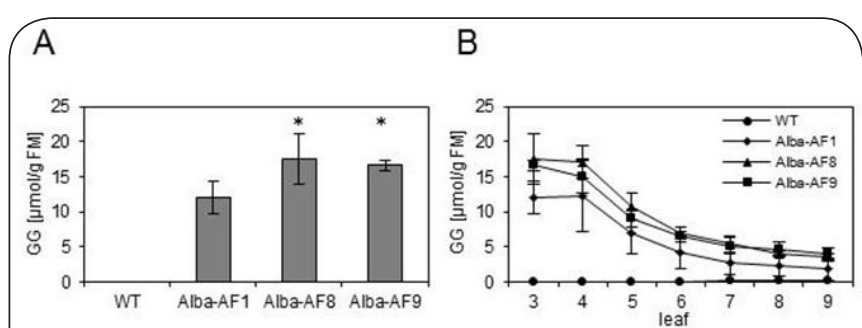

Figure 3. Comparison of the glucosylglycerol (GG) amount in leaf extracts of different transgenic potato clones by GC. (A) GG amounts in young leaves (3rd leave from the top of 4 weeks old plants grown under standard conditions); (B) GG amounts in leaves of different ages ( 3 - 9, youngest to oldest leaf, leaves were counted from the top). Mean values \pm SD (vertical bars) of one representative greenhouse experiment are shown. Statistical significant differences between GG contents of clone Alba-AFland the other two clones are marked by asterisk.

in the detected GG levels. Plants grown on MS medium showed lower $\mathrm{GG}$ accumulation ( 0.02 up to $0.6 \mu \mathrm{mol} \mathrm{GG} / \mathrm{g}$ FM) than plants cultivated in soil ( 0.2 up to $26 \mu \mathrm{mol} \mathrm{GG} / \mathrm{g} \mathrm{FM}$ in $3^{\text {rd }}$ leaves of 4 weeks old plants). Another striking difference in the GG amount became visible when leaves of different ages were compared. Older leaves, for example we analyzed different leaves of 4 weeks old plants (i.e., leaves 3 (youngest) - 9 (oldest) from the top were sampled), showed generally lower GG levels than younger leaves (Figure 3). Nevertheless, the quantitative differences among different transgenic plants of the series Alba-AF remained visible during all experimental series, i.e. plants having higher $\mathrm{GG}$ values in young leaves retained higher GG levels also in older or stressed leaves. Moreover, we observed significant GG accumulation in stolons (up to $20 \mu \mathrm{mol} G \mathrm{G} / \mathrm{g} \mathrm{FM}$ ), but GG was never found in fully developed tubers in potato plants with CaMV-35S-promoted ggpPS expression.

\section{Growth of plants controlling ggpPS expression by the CaMV 35S promoter}

For stress experiments three independently obtained transgenic clones (Alba-AF1, Alba-AF8, and Alba-AF9) were chosen. Alba-AF8 and Alba-AF9 plants showed rather high levels of GG accumulation (in young leaves $17 \mu \mathrm{mol} G \mathrm{G} / \mathrm{g}$ FM), while plants of the transgenic line Alba-AF1 showed significantly lower GG accumulation (30\% less) (Figure 3, Table 1). Under salt and drought stress all potato plants showed significant growth retardation compared to the plants grown under control conditions (Figure 4). However, we found significantly improved shoot growth of all transgenic GG-accumulating plants under drought stress conditions compared to drought-stressed wild-type plants. The transgenic clone Alba-AF1 also showed increased shoot heights under control and salt stress conditions compared to the wild-type and the other transgenic potatoes (Figure 4). 


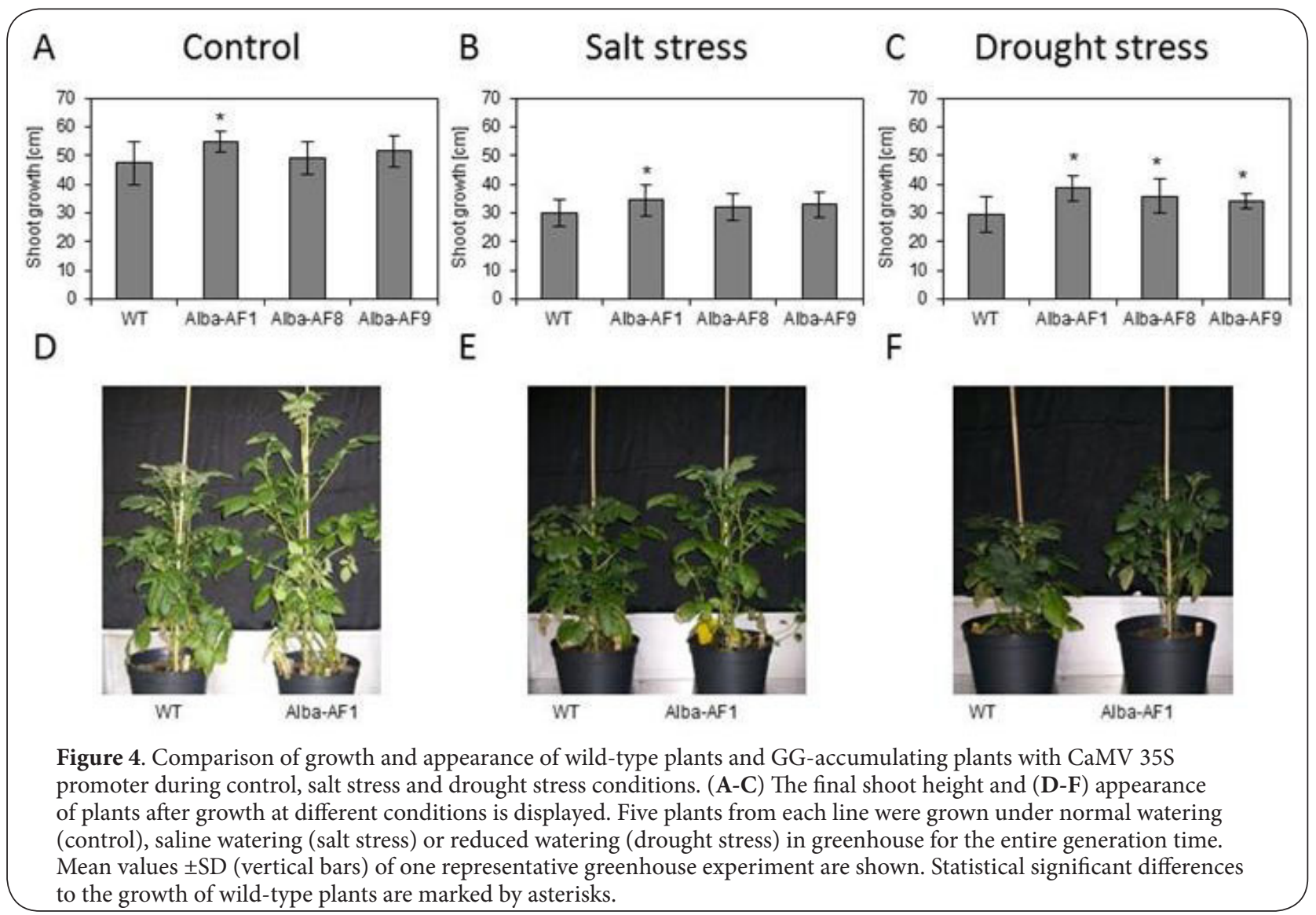

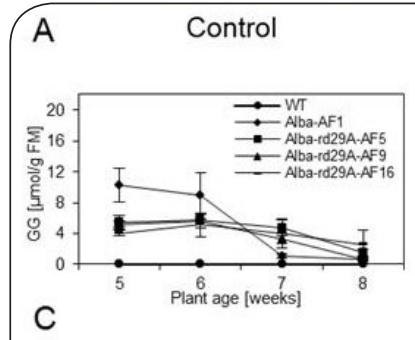
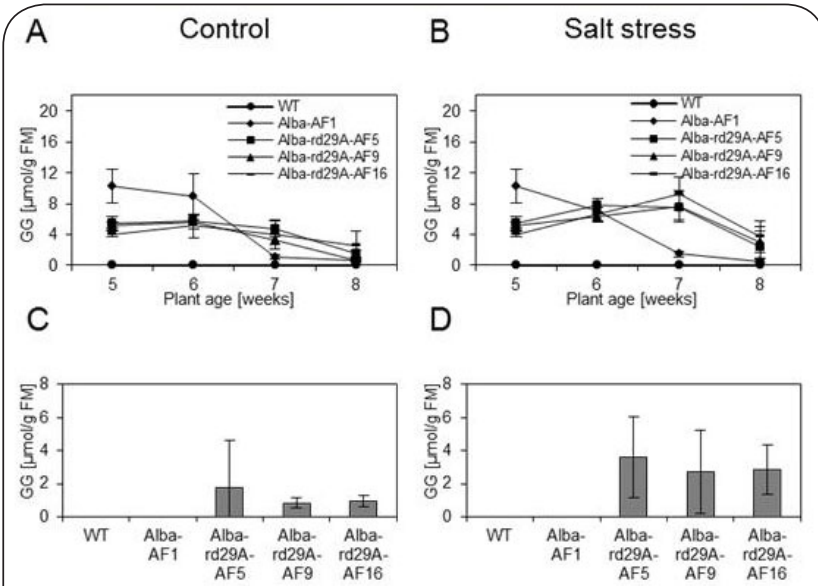

Figure 5. Comparison of the glucosylglycerol (GG) amount in the 3rd leave from the top of plants with rd29A promoter driven $g g p P S$ expression at different age $(\mathbf{A}, \mathbf{B})$ and in tuber extracts $(\mathbf{C}, \mathbf{D})$ of different transgenic potato clones grown under control $(\mathbf{A}, \mathbf{C})$ and salt stress $(\mathbf{B}, \mathbf{D})$ conditions, respectively.

Experiments with plants controlling ggpPS expression by the rd29A promoter

Additionally, we generated transgenic potato plants with ggpPS under control of the rd29A promoter [35] (Series
Alba-rd29A-AF). Despite the control of ggpPS expression by the salt-stress-induced rd29A promoter, we also found GG accumulation in these transgenic clones under control conditions (Figure 5, Table 1). Under control conditions, the GG levels in young leaves of plants of the series Alba-rd29AAF were 2-3times lower than in plants of the series Alba-AF. However, application of a salt stress doubled the GG amount in transgenic clones of the series Alba-rd29A-AF compared to plants of the same genotype grown under control conditions (Table 1). Moreover, GG remained detectable in leaves of the salt-stressed Alba-rd29A-AF plants till the end of the 8 weeks growth period, i.e. we found no sharp decrease in GG levels of older leaves (Figure 5). Interestingly, in this plant series GG also was found in tubers. While under control conditions only low GG levels with high variation were detected, salt stress significantly increased the amount of GG in tubers, it reached up to $5 \mu \mathrm{mol}$ GG/g FM (Figure 5).

Three transgenic clones with relatively high levels of $G G$ accumulation (Alba-rd29A-AF5, Alba-rd29A-AF9, and Albard29A-AF16) were chosen for salt stress experiments in the greenhouse. Again, under salt stress conditions all potato plants showed significant growth retardation compared to control conditions (Figure 6). However, we found significant improved shoot growth of the transgenic plants of clone Albard29A-AF16 under salt stress conditions, comparable to the 
Sievers et al. Journal of Plant Science \& Molecular Breeding 2013,

http://www.hoajonline.com/journals/pdf/2050-2389-2-1.pdf

doi: $10.7243 / 2050-2389-2-1$

Table 1. Contents of low molecular mass compounds in young leaves (leaf number 3 ) of wild-type potato plants and GGaccumulating transgenic clones (Means \pm confidence intervals, $\alpha=0.05)$. Statistical significant differences between transgenic and corresponding wild-type plants are shown in bold face. Samples were taken before the stress and 4 week after treatments with normal watering (control), with salt-enriched watering (salt stress), or with reduced watering (drought stress).

\begin{tabular}{|c|c|c|c|c|c|}
\hline \multirow[t]{2}{*}{ Plant } & \multicolumn{5}{|c|}{$\mu \mathrm{mol} / \mathrm{g}$ fresh mass } \\
\hline & GG & Sucrose & Fructose & Glucose & Sum \\
\hline \multicolumn{6}{|c|}{ Before stress } \\
\hline WT & 0 & $2.19 \pm 1.26$ & $9.06 \pm 1.68$ & $7.31 \pm 1.18$ & 18.56 \\
\hline Alba-AF1 & $12.87 \pm 2.42$ & $1.11 \pm 0.73$ & $6.36 \pm 1.07$ & $5.94 \pm 1.43$ & 26.28 \\
\hline Alba-AF8 & $11.91 \pm 2.25$ & $0.94 \pm 0.50$ & $5.66 \pm 0.90$ & $5.14 \pm 1.18$ & 23.65 \\
\hline Alba-AF9 & $10.96 \pm 2.03$ & $1.17 \pm 0.81$ & $6.18 \pm 0.94$ & $5.43 \pm 1.08$ & 23.74 \\
\hline \multicolumn{6}{|c|}{4 weeks control } \\
\hline WT & 0 & $1.39 \pm 0.24$ & $6.99 \pm 1.11$ & $5.15 \pm 0.70$ & 13.53 \\
\hline Alba-AF1 & $0.22 \pm 0.20$ & $2.97 \pm 1.09$ & $8.43 \pm 2.31$ & $6.77 \pm 1.25$ & 18.39 \\
\hline Alba-AF8 & $0.14 \pm 0.13$ & $1.60 \pm 0.48$ & $5.48 \pm 1.29$ & $4.50 \pm 0.75$ & 11.72 \\
\hline Alba-AF9 & $0.27 \pm 0.21$ & $1.89 \pm 0.63$ & $5.82 \pm 1.38$ & $4.79 \pm 0.93$ & 12.77 \\
\hline \multicolumn{6}{|c|}{4 weeks salt stress } \\
\hline WT & 0 & $4.17 \pm 1.12$ & $1.93 \pm 0.52$ & $1.98 \pm 0.42$ & 8.08 \\
\hline Alba-AF1 & $0.07 \pm 0.03$ & $7.23 \pm 1.81$ & $2.37 \pm 0.56$ & $2.57 \pm 0.50$ & 12.24 \\
\hline Alba-AF8 & $0.03 \pm 0.01$ & $7.66 \pm 1.89$ & $2.29 \pm 0.64$ & $2.17 \pm 0.48$ & 12.15 \\
\hline Alba-AF9 & $0.08 \pm 0.03$ & $7.46 \pm 1.48$ & $2.31 \pm 0.50$ & $2.34 \pm 0.45$ & 12.19 \\
\hline \multicolumn{6}{|c|}{4 weeks drought stress } \\
\hline WT & 0 & $2.28 \pm 0.73$ & $8.80 \pm 1.78$ & $6.48 \pm 1.35$ & 17.56 \\
\hline Alba-AF1 & $0.08 \pm 0.04$ & $3.21 \pm 0.29$ & $9.97 \pm 1.53$ & $8.32 \pm 0.97$ & 21.58 \\
\hline Alba-AF8 & $0.04 \pm 0.02$ & $3.26 \pm 0.90$ & $9.99 \pm 3.65$ & $8.03 \pm 3.32$ & 21.32 \\
\hline Alba-AF9 & $0.07 \pm 0.03$ & $2.93 \pm 0.55$ & $8.05 \pm 1.11$ & $6.43 \pm 0.93$ & 17.48 \\
\hline \multicolumn{6}{|c|}{ Before stress } \\
\hline WT & 0 & $1.23 \pm 0.51$ & $2.67 \pm 0.81$ & $2.94 \pm 0.83$ & 6.84 \\
\hline Alba-rd29A-AF5 & $5.46 \pm 0.58$ & $0.73 \pm 0.28$ & $1.51 \pm 0.48$ & $2.26 \pm 0.52$ & 9.96 \\
\hline Alba-rd29A-AF9 & $5.24 \pm 0.28$ & $0.63 \pm 0.36$ & $1.99 \pm 0.64$ & $2.69 \pm 0.57$ & 10.55 \\
\hline Alba-rd29A-AF16 & $4.03 \pm 0.24$ & $0.54 \pm 0.30$ & $1.83 \pm 0.56$ & $2.45 \pm 0.41$ & 8.85 \\
\hline \multicolumn{6}{|c|}{4 weeks control } \\
\hline WT & 0 & $2.96 \pm 0.57$ & $1.95 \pm 0.35$ & $2.18 \pm 0.36$ & 7.09 \\
\hline Alba-rd29A-AF5 & $4.73 \pm 0.74$ & $2.21 \pm 0.78$ & $2.02 \pm 0.40$ & $2.79 \pm 0.36$ & 11.75 \\
\hline Alba-rd29A-AF9 & $3.34 \pm 0.43$ & $2.96 \pm 0.64$ & $2.16 \pm 0.45$ & $2.84 \pm 0.46$ & 11.30 \\
\hline Alba-rd29A-AF16 & $4.03 \pm 1.36$ & $1.67 \pm 0.85$ & $4.67 \pm 1.37$ & $5.71 \pm 1.47$ & 16.08 \\
\hline \multicolumn{6}{|c|}{4 weeks salt stress } \\
\hline WT & 0 & $1.30 \pm 0.71$ & $4.88 \pm 1.02$ & $5.61 \pm 0.89$ & 11.79 \\
\hline Alba-rd29A-AF5 & $7.52 \pm 1.17$ & $0.83 \pm 0.67$ & $3.35 \pm 0.44$ & $5.45 \pm 0.42$ & 17.15 \\
\hline Alba-rd29A-AF9 & $7.67 \pm 1.45$ & $0.39 \pm 0.12$ & $4.04 \pm 0.40$ & $5.85 \pm 0.93$ & 17.95 \\
\hline Alba-rd29A-AF16 & $9.26 \pm 1.51$ & $0.71 \pm 0.43$ & $4.99 \pm 0.89$ & $6.74 \pm 0.97$ & 21.70 \\
\hline
\end{tabular}

phenomenon in clone Alba-AF1. Interestingly, all transgenic lines also showed significantly increased shoot heights under control conditions compared to wild type (Figure 6).

\section{Effects of GG accumulation on contents of soluble sugars in potato leaves}

Additional to GG, we estimated the amounts of sucrose, glucose and fructose in leaves. Analyses of extracts from the $3^{\text {rd }}$ leaf of 4 weeks old potato plants (Table 1, data of plants before stress) showed that the total sugar amount of the transgenic clones was higher than in wild-type plants. This difference was observed in both types of transgenic potato, i.e. plants expressing the ggpPS gene under control of the CaMV 355 promoter as well
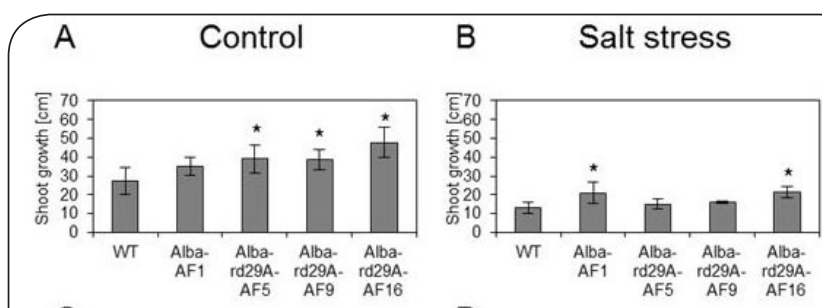

C

D
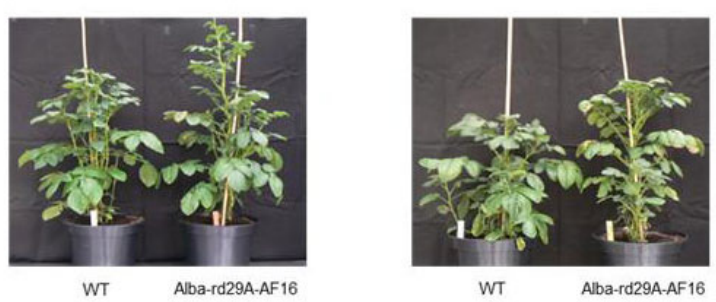

Figure 6. Comparison of growth and appearance of wild-type plants and GG-accumulating clones with CaMV 35S (AlbaAF1) or rd29A (Alba-rd29A-AF5, -AF9, -AF16, respectively) promoter controlling the ggpPS expression during control and salt stress conditions. (A-B) The final shoot height and (C-D) appearance of plants after growth at different conditions is displayed. Five plants from each line were grown under normal watering (control) and saline watering (salt stress) in greenhouse for the entire generation time. Mean values \pm SD (vertical bars) of one representative greenhouse experiment are shown. Statistical significant differences to the growth of wild-type plants are marked by asterisks.

as of the rd29A promoter. The increased amount of total soluble compounds is mainly due to the accumulated GG, whereas the levels of sucrose, glucose and fructose were slightly lower in transgenic plants compared to wild-type plants. The difference in total soluble sugars between wildtype and transgenic plants of the series Alba-AF disappeared when 8 weeks old plants were analyzed grown under control conditions. In those plants the amount of GG decreased to trace amounts, while the contents of sucrose, fructose and glucose were comparable between transgenic and wild-type plants (Table 1). In contrast, leaves of the 8 weeks old transgenic plants of the series Alba-rd29A-AF retained elevated contents of total soluble compounds, because in plants of this series GG did not disappear. The amounts of sucrose, glucose and fructose showed levels similar to wild-type plants.

Comparing wild-type and transgenic plants of the series Alba-AF revealed that under drought stress conditions the amount of total soluble compounds increased, while salt stress seems to decrease it (Table 1). Under both stress conditions, leaves of transgenic plants contained about $20 \%$ higher total amounts of total soluble sugars compared to wild type. While the amount of GG was comparable low in control, salt-stressed, and drought-stressed plants, transgenic plants contained significantly more sucrose and slightly more glucose and fructose under drought stress conditions.

In contrast, plants of the series Alba-rd29A-AF clearly 
increased the amount of soluble compounds under salt stress (Table 1). This enhancement of soluble sugars is mainly based on the salt-triggered increase in the GG levels, since the expression of the ggpPS gene is controlled by the salt-stressregulated rd29A promoter. The amounts of sucrose, glucose and fructose became slightly lowered in transgenic compared to wild-type plants under salt stress conditions.

\section{Discussion}

In the present study the gene ggpPS, encoding the enzymes for biosynthesis of GG from $A$. vinelandii, was successfully expressed in potato as before in Arabidopsis [30]. The amount of GG detected in the transgenic lines was rather high; it exceeded about 10times the sucrose level in young leaves. The GG levels were similar to that observed in our previous study using Arabidopsis as a host [30]. Also in potato plants, these high amounts were tolerated without any strong pleiotropic effects, which can be taken as a clear indication for the compatibility of $\mathrm{GG}$ with plant metabolism in general. This finding is in contrast to several other studies, where the synthesis of compatible compounds (e.g. sorbitol) after transgene expression was accompanied by pleiotropic effects such as infertility or necrosis, when the content of the compound exceeded $5 \mu \mathrm{mol} / \mathrm{g} \mathrm{FM}$ (e.g. [13]). In fact, the high level GG-accumulating potato plants showed even better growth under standard conditions, whereas the GG-accumulating Arabidopsis plants rather showed a negative correlation between GG level and growth, i.e. transgenic lines with GG-levels of $20 \mu \mathrm{mol} / \mathrm{g}$ FM showed smaller rosette diameters whereas plants accumulating only $2 \mu \mathrm{mol} / \mathrm{g} \mathrm{FM}$ were not affected [30].

In contrast to GG-accumulating Arabidopsis [30], we observed changes in GG accumulation depending on the age of the plant when the ggpPS gene was expressed by the constitutive CaMV 35 S promoter. Generally, young developing leaves and also stolons contained high amounts of GG, whereas fully developed source leaves and tubers were virtually free of GG. This change was not expected because the ggpPS gene in plants of the series Alba-AF is expressed by the CaMV $35 \mathrm{~S}$ promoter thought to be constitutively active in plants. However, there are reports on expression differences in plant organs of different ages using this promoter for transgene expression $[36,37,38]$. Our semi-quantitative RT-PCR showed almost similar ggpPS-mRNA levels in young and old leaves, stolons and tubers as well. Obviously, expression changes are not sufficient to explain the developmental change of GG accumulation. Interestingly, sucrose contents showed a behavior opposite to that of $\mathrm{GG}$, i.e. young organs contained rather low sucrose amounts which increased during further age (see Table 1). Both, the biosynthesis of GG and sucrose use UDP-glucose as precursor. Moreover, older leaves develop to source organs exporting high amounts of sucrose to other plant parts. This differentiation is accompanied by an increased expression of enzyme sucrose-phosphate synthase (SPS) in older potato leaves [39]. Possibly, the competition for precursors and/or the developmental increased sucrose synthesis could explain the diminished GG levels. We also noticed that the GG amount in transgenic potato plants was much lower when shoots are grown on sucrose-containing MS medium, which indicates that sucrose itself might have a negative regulatory effect on GG synthesis. Sucrose and especially hexoses are known to act as direct regulators on numerous processes in plants [40]. Moreover, a GG degrading activity or its export could become active in older leaves, since sampling of the same leave at different time points revealed also a disappearance of GG in leaves initially characterized by high GG levels.

We also generated plants in which the expression of this transgene was controlled by the salt-stress-regulated promoter rd29A. This promoter was identified in Arabidopsis and shown to have a basal expression, which is significantly increased under high salt and other stress conditions [35,41]. There are many reports that the stress-regulation of $\mathrm{rd} 29 \mathrm{~A}$ is not only found in its native host Arabidopsis but also in crop plants such as potato (own results, [34,42]), rice [43], mulberry [44], soybean [45], and peanut [46]. The relatively stable GG accumulation in transgenic potatoes of the series Alba-rd29AAF indicated that changes in the relative expression of $g g p P S$ and genes for competing enzymes such as sps might be at least partly responsible for the developmental change in GG accumulation in plants expressing ggpPS by CaMV $35 S$ promoter. The increase of rd29A-controlled ggpPS expression under salt stress conditions (data not shown) resulted in doubled GG amounts in older leaves (Table 1) and elevated GG levels in tubers. Again, a reverse relation of GG and sucrose is visible, i.e. salt-stressed plants with enhanced $\mathrm{GG}$ levels decreased the sucrose levels, while leaves of older control plants with slightly decreased GG amounts contained more sucrose. Summarizing, the use of the stress-inducible rd29A promoter offered clear advantages for the stable expression of ggpPS in potatoes compared to the CaMV $35 \mathrm{~S}$ promoter control.

The presence of high amounts of GG in the transgenic potatoes made it promising to search for improvements of tolerance towards salt stress in greenhouse experiments. In the case of GG accumulation in transgenic potato plants we found an increase in shoot growth under control and drought stress conditions of up to $30 \%$. This growth improvement was found with plants obtained from independent explants. Similar growth promoting effects under control and stress conditions were reported before for the GG-accumulating model Arabidopsis [30]. Comparable to Arabidopsis, only plants of the clone Alba-AF1 and Alba-rd29A-AF16 with an intermediate $\mathrm{GG}$ amount showed an improved growth under salt stress conditions, while plants of clones with higher GG accumulation (e.g. Alba-AF8 or Alba-AF9) showed no salt-stress improvement. Whereas the plants of the series Alba-rd29A-AF contained high GG amounts during the whole experiment, plants of the series Alba-AF retained only traces of GG. These findings point for a more direct protective effect of GG for critical macromolecules rather than an osmotic effect. That 
GG is effective to protect macromolecules against denaturation has been proven with many in vitro systems $[\mathbf{2 8}, \mathbf{2 9}, \mathbf{3 1}]$. The improved fitness of salt and drought-stressed transgenic potato plants can also be related to the overall increase of soluble sugars inside leaves.

Compared to the constitutive expression of ggpPS, potato plants expressing the transgene ggpPS under control of the stress-regulated promoter rd29A seem to be more suitable for future application. These plants show a stable and stress-induced GG accumulation in all organs. Beside an improved shoot growth under control and salt-stress conditions, these GG-accumulating plants can also be used as source of this compatible solute with potential use in cosmetics and pharmaceuticals [31].

\section{Competing interests}

The authors declare that they have no competing interests.

Acknowledgement

This work was supported by a grant of the BMVL

(Bundesministerium für Verbaucherschutz und Landwirtschaft)

FKZ 22003006 via the FNR (Fachagentur für Nachwachsende

Rohstoffe Mecklenburg/Vorpommern) Germany.

Publication history

Received: 28-Dec-2012 Revised: 04-Feb-2013

Re-Revised: 18-Feb-2013 Accepted: 19-Feb-2013

Published: 25-Feb-2013

\section{References}

1. Apse MP and Blumwald E: Engineering salt tolerance in plants. Curr Opin Biotechnol 2002, 13:146-50. | Article | PubMed

2. Flowers TJ: Improving crop salt tolerance. J Exp Bot 2004, 55:307-19. | Article | PubMed

3. Mittler $\mathrm{R}$ and Blumwald $\mathrm{E}$ : Genetic engineering for modern agriculture: challenges and perspectives. Annu Rev Plant Biol 2010, 61:443-62. I Article | PubMed

4. Brown AD: Compatible solutes and extreme water stress in eukaryotic micro-organisms. Adv Microb Physiol 1978, 17:181-242. | Article | PubMed

5. Potts M: Desiccation tolerance of prokaryotes. Microbiol Rev 1994, 58:755-805. | Article | PubMed Abstract | PubMed Full Text

6. Hong Z, Lakkineni K, Zhang Z and Verma DP: Removal of feedback inhibition of delta(1)-pyrroline-5-carboxylate synthetase results in increased proline accumulation and protection of plants from osmotic stress. Plant Physiol 2000, 122:1129-36. | Article | PubMed Abstract | PubMed Full Text

7. Goddijn OJ, Verwoerd TC, Voogd E, Krutwagen RW, de Graaf PT, van Dun K, Poels J, Ponstein AS, Damm B and Pen J: Inhibition of trehalase activity enhances trehalose accumulation in transgenic plants. Plant Physiol 1997, 113:181-90. | Article | PubMed Abstract | PubMed Full Text

8. Nuccio ML, Rhodes D, McNeil SD and Hanson AD: Metabolic engineering of plants for osmotic stress resistance. Curr Opin Plant Biol 1999, 2:12834. | Article | PubMed

9. Chen TH and Murata N: Glycinebetaine protects plants against abiotic stress: mechanisms and biotechnological applications. Plant Cell Environ 2011, 34:1-20. | Article | PubMed

10. Holmström KO, Mäntylä E, Wellin B, Manfal A, Palva ET, Tunnela OE, Londesborough J: Drought tolerance in tobacco. Nature 1996, 379:683684. | Article

11. Pilon-Smits EA, Terry N, Sears T, Kim H, Zayed A, Hwang A, van Dun K, Voogd E, Verwoerd T, Krutwagen RW, Goddijin OJ: Trehalose producing transgenic tobacco plants show improved growth performance under drought stress. J Plant Physiol 1998, 152:525-532. I Article

12. Tarczynski MC, Jensen RG and Bohnert HJ: Stress protection of transgenic tobacco by production of the osmolyte mannitol. Science 1993, 259:508-10. | Article | PubMed

13. Sheveleva EV, Marquez S, Chmara W, Zegeer A, Jensen RG and Bohnert $\mathrm{HJ}$ : Sorbitol-6-phosphate dehydrogenase expression in transgenic tobacco. High amounts of sorbitol lead to necrotic lesions. Plant Physiol 1998, 117:831-9. | Article | PubMed Abstract | PubMed Full Text

14. Nuccio ML, Russell BL, Nolte KD, Rathinasabapathi B, Gage DA and Hanson AD: The endogenous choline supply limits glycine betaine synthesis in transgenic tobacco expressing choline monooxygenase. Plant J 1998, 16:487-96. | Article | PubMed

15. Waditee R, Bhuiyan MN, Rai V, Aoki K, Tanaka Y, Hibino T, Suzuki S, Takano J, Jagendorf AT and Takabe T: Genes for direct methylation of glycine provide high levels of glycinebetaine and abiotic-stress tolerance in Synechococcus and Arabidopsis. Proc Natl Acad Sci U S A 2005, 102:1318-23. | Article | PubMed Abstract | PubMed Full Text

16. Nakayama H, Yoshida K, Ono H, Murooka $Y$ and Shinmyo A: Ectoine, the compatible solute of Halomonas elongata, confers hyperosmotic tolerance in cultured tobacco cells. Plant Physiol 2000, 122:1239-47. Article | PubMed Abstract | PubMed Full Text

17. Hagemann M: Molecular biology of cyanobacterial salt acclimation. FEMS Microbiol Rev 2011, 35:87-123. | Article | PubMed

18. Reed RH, Stewart WDP: Osmotic adjustment and organic solute accumulation in unicellular cyanobacteria from freshwater and marine habitats. Mar Biol 1985, 88:1-9. | Article

19. Klahn S and Hagemann M: Compatible solute biosynthesis in cyanobacteria. Environ Microbiol 2011, 13:551-62. | Article | PubMed

20. Hagemann M, Erdmann N: Activation and pathway of glucosylglycerol biosynthesis in the cyanobacterium Synechocystis sp. PCC 6803. Microbiology 1994, 140:1427-1431. | Article

21. Hagemann $M$, Schoor $A$, Jeanjean $R$, Zuther $E$ and Joset $F$ : The stpA gene form Synechocystis sp. strain PCC 6803 encodes the glucosylglycerol-phosphate phosphatase involved in cyanobacterial osmotic response to salt shock. J Bacteriol 1997, 179:1727-33. | Article | PubMed Abstract | PubMed Full Text

22. Marin K, Zuther E, Kerstan T, Kunert A and Hagemann M: The ggpS gene from Synechocystis sp. strain PCC 6803 encoding glucosyl-glycerol-phosphate synthase is involved in osmolyte synthesis. J Bacteriol 1998, 180:4843-9. | Article | PubMed Abstract | PubMed Full Text

23. Pocard JA, Smith LT, Smith GM and Le Rudulier D: A prominent role for glucosylglycerol in the adaptation of Pseudomonas mendocina SKB70 to osmotic stress. J Bacteriol 1994, 176:6877-84. | Article | PubMed Abstract | PubMed Full Text

24. Roder A, Hoffmann E, Hagemann M and Berg G: Synthesis of the compatible solutes glucosylglycerol and trehalose by salt-stressed cells of Stenotrophomonas strains. FEMS Microbiol Lett 2005, 243:219-26. | Article I PubMed

25. Hagemann M, Ribbeck-Busch K, Klahn S, Hasse D, Steinbruch R and Berg G: The plant-associated bacterium Stenotrophomonas rhizophila expresses a new enzyme for the synthesis of the compatible solute glucosylglycerol. J Bacteriol 2008, 190:5898-906. | Article | PubMed Abstract | PubMed Full Text

26. Bianchi G, Gamba A, Limiroli R, Pozzi N, Elster R, Salamini F, Bartels D: The unusual sugar composition in leaves of the resurrection plant Myrothamnus flabellifolia. Physiol Plant 2006, 87:223-226. | Article

27. Kaneda M, Kobayashi K, Nishida K, Katsuta S: Liliosides D and F, two glycerol glucosides from Lilium japonicum. Phytochemistry 1984, 23:795-798.

28. Borges N, Ramos A, Raven ND, Sharp RJ and Santos H: Comparative study of the thermostabilizing properties of mannosylglycerate and other compatible solutes on model enzymes. Extremophiles 2002, 6:209-16. | Article | PubMed

29. Hincha DK and Hagemann M: Stabilization of model membranes during drying by compatible solutes involved in the stress tolerance of plants and microorganisms. Biochem J 2004, 383:277-83. | Article | 
Sievers et al. Journal of Plant Science \& Molecular Breeding 2013, http://www.hoajonline.com/journals/pdf/2050-2389-2-1.pdf

PubMed Abstract | PubMed Full Text

30. Marquardt DM, Rollwitz I and Hagemann M: Expression of the ggpPS gene for glucosylglycerol biosynthesis from Azotobacter vinelandii improves the salt tolerance of Arabidopsis thaliana. J Exp Bot 2009, 60:1679-89. | Article | PubMed Abstract | PubMed Full Text

31. Sawangwan T, Goedl C and Nidetzky B: Glucosylglycerol and glucosylglycerate as enzyme stabilizers. Biotechnol J 2010, 5:187-91. | Article | PubMed

32. Murashige T, Skoog F: A revised medium for rapid growth and bio assay with tobacco tissue cultures. Physiol Plant 1962, 15:73-497. | Article

33. Hausmann L, Töpfer R: Entwicklung von Plasmid-Vektoren. In Brauer $D$, Roebbelen $G$, Töpfer $R$ (eds) BioEngineering für Rapssorten nach Maß, Vorträge für Pflanzenzüchtung 45, GPZ, Quedlinburg, 1999: pp 153-171.

34. Zhang N, Si HJ, Wang D: Cloning of rd29A gene promoter from Arabidopsis thaliana and its application in stress-resistance transgenic potato. Acta Agr Sinica 2005, 2:83-88.

35. Yamaguchi-Shinozaki K and Shinozaki K: Characterization of the expression of a desiccation-responsive rd29 gene of Arabidopsis thaliana and analysis of its promoter in transgenic plants. Mol Gen Genet 1993, 236:331-40. | Article | PubMed

36. Terada R, Simamoto K: Expression of the CaMV35S-GUS gene in transgenic rice plants. Mol Gen Genet 1990, 220:389-392. I Article

37. Holtorf S, Apel K and Bohlmann H: Comparison of different constitutive and inducible promoters for the overexpression of transgenes in Arabidopsis thaliana. Plant Mol Biol 1995, 29:637-46. | Article | PubMed

38. Sunilkumar G, Mohr L, Lopata-Finch E, Emani C and Rathore KS: Developmental and tissue-specific expression of CaMV $35 \mathrm{~S}$ promoter in cotton as revealed by GFP. Plant Mol Biol 2002, 50:463-74. | Article | PubMed

39. Reimholz R, Geiger M, Haake V, Deiting U, Krause K.P., Sonnewald U, Stitt M: Potato plants contain multiple forms for sucrose phosphate synthase, which differ in their tissue distributions, their levels during development, and their responses to low temperature. Plant Cell Environ 1997, 20:291-305. | Article

40. Jang JC, Leon $P$, Zhou $L$ and Sheen J: Hexokinase as a sugar sensor in higher plants. Plant Cell 1997, 9:5-19. | Article | PubMed Abstract | PubMed Full Text

41. Yamaguchi-Shinozaki K and Shinozaki K: A novel cis-acting element in an Arabidopsis gene is involved in responsiveness to drought, low-temperature, or high-salt stress. Plant Cell 1994, 6:251-64. | Article | PubMed Abstract | PubMed Full Text

42. Pino MT, Skinner JS, Park EJ, Jeknic Z, Hayes PM, Thomashow MF and Chen TH: Use of a stress inducible promoter to drive ectopic AtCBF expression improves potato freezing tolerance while minimizing negative effects on tuber yield. Plant Biotechnol J 2007, 5:591-604. | Article I PubMed

43. Datta K, Baisakh N, Ganguly M, Krishnan S, Yamaguchi Shinozaki K and Datta SK: Overexpression of Arabidopsis and rice stress genes' inducible transcription factor confers drought and salinity tolerance to rice. Plant Biotechnol J 2012, 10:579-86. | Article | PubMed

44. Checker VG, Chhibbar AK and Khurana P: Stress-inducible expression of barley Hva1 gene in transgenic mulberry displays enhanced tolerance against drought, salinity and cold stress. Transgenic Res 2012, 21:93957. | Article | PubMed

45. Polizel AM, Medri ME, Nakashima K, Yamanaka N, Farias JR, de Oliveira MC, Marin SR, Abdelnoor RV, Marcelino-Guimaraes FC, Fuganti R, et al: Molecular, anatomical and physiological properties of a genetically modified soybean line transformed with rd29A:AtDREB1A for the improvement of drought tolerance. Genet Mol Res 2011, 10:3641-56. I Article I PubMed

46. Bhatnagar-Mathur P, Devi MJ, Reddy DS, Lavanya M, Vadez V, Serraj R, Yamaguchi-Shinozaki K and Sharma KK: Stress-inducible expression of At DREB1A in transgenic peanut (Arachis hypogaea L.) increases transpiration efficiency under water-limiting conditions. Plant Cell Rep 2007, 26:2071-82. | Article | PubMed

\section{Citation:}

Sievers N, Muders K, Henneberg M, Klähn S, Effmert $\mathrm{M}$, Junghans $\mathrm{H}$ and Hagemann $\mathrm{M}$ : Establishing glucosylglycerol synthesis in potato (Solanum tuberosum l. cv. Albatros) by expression of the ggpPS gene from Azotobacter vinelandii. Journal of Plant Science and Molecular Breeding 2013, 2:1. http://dx.doi.org/10.7243/2050-2389-2-1 